EKAIA (2022), artikulua prentsan/article in press. https://doi.org/10.1387/ekaia.22936

Behin-behineko bertsioa (euskara-orrazketaren faltan).
ISSN: 0214-9001 e-ISSN: 2444-3255 (CUPV/EHU Press

\title{
Animalia jatorridun hondakinen balio-ematea: aktibazio-estrategiak eta erabilgarritasuna hainbat industria-prozesutan
}

\author{
(Animal-waste valorisation: activation strategies and industrial applications)

$$
\begin{aligned}
& \text { Unai Iriarte }^{1 *} \text {,Urtzi Arteagabeitia }{ }^{1} \text {, Eva Epelde }{ }^{2} \text {, Jose Luis Ayastuy }{ }^{2} \text {, Irene Sierra } \\
& \\
& { }^{1} \text { Ingeniaritza Kimikoa Saila, Farmazia Fakultatea (UPV/EHU), Gasteiz } \\
& { }^{2} \text { Ingeniaritza Kimikoa Saila, Zientzia eta Teknologia Fakultatea (UPV/EHU), Leioa }
\end{aligned}
$$

LABURPENA: Animalia-haragi eta hezur-hondakinak gero eta arazo larriagoa bihurtu dira egungo kontsumo ohituren ondorioz. XX. mendearen amaieran "behi eroen gaixotasuna" bezala ezagutu genuen osasun-krisia eta gero, abereen elikadurarako erabiltzen ziren animalia-hondakin ehunka tona erabilpenik gabe geratu ziren. Harrezkero, zabortegietara bideratutako hondakin kantitatea nabarmen handitu da. Geroztik egindako ikerketen arabera, hainbat aplikaziotan hezurikatza material oso erabilgarria izan daitekeela ikusi da. Adibidez, kutsatzaileen degradazio- edo ezabatze-prozesutan, neurri batean hezur-ikatzaren osagai nagusia den apatitoak, uretan duen disolbagarritasun txikiagatik eta ioiak trukatzeko duen ahalmen handiagatik. Hezur-ikatzetik eratorritako materialak ere modu arrakastatsuan erabili dira euskarri katalitiko gisa eta prozesu elektrokimikoetan. Material horren aplikagarritasuna, bere egitura porotsuarekin dago zuzenean lotuta. Lan honetan, hezurretatik material erabilgarriak lortzeko gaur egun ikertzen ari diren prozesuak azalduko dira. Hezur-ikatzaren porotasun-maila ezberdina garatzeko aktibazio kimiko edo kimiko-fisiko egokiak beharrezkoak dira. Aktibazio kimiko-fisikoa, soilik fisikoa baino abantailatsuagoa izan ohi da ezaugarri hobeak lortzen direlako solidoan, bai etekinaren aldetik eta bai gainazal azaleraren aldetik (biak handiagoak). Halaber, tratamendu kimiko-fisikoa erabiltzen denean kiskaltze-tenperatura txikiagoa erabil daitekeenez, honek ehundura-ezaugarri hobeak erdiesten ditu, orohar. Metodo eta teknika ezberdinen aplikazioei esker, animalia-hondakin solidoen balio-ematea bideragarria dela frogatuko da. Halaber, halako teknologia garatzeko gai izanez gero, zabortegietako metaketak nabarmen murriztuko lirateke, beti ere ingurumenaren jasangarritasuna bermatuz.

HITZ GAKOAK: animalia-hondakinak; apatitoa; aktibazio kimiko eta fisikoa.

\begin{abstract}
Waste animal bones have become a serious concern due to the current consumer habits. After the so called "mad cow disease" crisis, hundreds of tons of waste animal bones, which were so far used to manufacture animal feed, had no way out anymore. Consequently, the amount of waste that reaches dumping sites notably increased. Several research studies, carried out since then, have concluded that bone char can be a useful material in several applications. For instance, in pollutant remediation, since its main constituent, apatite is a water-soluble mineral, which possess a high ion-exchange capacity. Bone char has also been successfully used as catalytic support and in electrochemical applications. Indeed, its applicability depends on its porous structure. This work aims to present the strategies that are nowadays in use for bone char preparation. Adequate porosity requires physical and/or chemical activation. A combination of chemical and physical activation is commonly a better choice since it provides a char with more advantageous properties, in terms of product yield and textural properties. Moreover, a previous chemical treatment allows reducing the highest treatment temperature. Different methods and techniques are available for the valorisation of waste animal bones. The development of adequate treatment strategies could reduce the waste disposal in landfills, with the consequent environmental benefit.
\end{abstract}

KEYWORDS: animal-waste; apatite; chemical and physical activation.

1

*Harremanetan jartzeko/ Corresponding author: Unai Iriarte, Ingeniaritza Kimikoa Saila, Farmazia Fakultatea (UPV/EHU), Gasteiz. ํㅜ https://orcid.org/ 0000-0001-6269-6427, unai.iriarte@ehu.eus

Nola aipatu / How to cite: 1 Iriarte, Unai; 2. Arteagabeitia, Urtzi; 3 Epelde, Eva; 4 Ayastuy, Jose Luis; 5 Sierra, Irene (2022). $<<$ Animalia jatorridun hondakinen balio-ematea: aktibazio-estrategiak eta erabilgarritasuna hainbat industria-prozesutan >>, Ekaia,. (https://doi.org/10.1387/ekaia.22936)

Jasoa: ekainak 24, 2021; Onartua: urtarrilak 20, 2022

ISSN 0214-9001-eISSN 2444-3225 / @ 2022 UPV/EHU 


\section{SARRERA}

1986. urtean, Erresuma Batuan “behien entzefalopatia espongiforme” bezala ezagutzen den osasunkrisia gertatu zen. Honek, gizartean sekulako kezka sortzeaz gain, zientzialarien artean ere ardura handia sortu zuen, prioi izeneko eragile kutsakor berri baten agerpenagatik [1]. Denbora laburrean, gainera, Asia eta Amerikan zehar hedatu zen gaixotasuna. Prioi proteinek etengabeko nahasmen neurodegeneratiboak eragin ditzakete, abereen kasuan behi eroen sindromea eta gizakion kasuan Creutzfeldt-Jakob gaixotasuna sortuz. Osasun-krisiaren jatorria animalia-haragiekin eta hezurrekin (behi, txerri zein ardi) egindako irinak zirela ondorioztatu zen, irin bihurtzeko prozesuetan hondakin horiei egindako tratamendu termikoa ez baita nahikoa prioiak desaktibatzeko (WHO, 2005) [2]. Horregatik, ganadua elikatzeko hondakin-mota horiek erabiltzea debekatu egin zen Europar Batasunean [3], krisi aurretik irtenbidea zeukaten ehunka animalia-hondakin tona, jada erabilera gabe geldituz.

Animalien haragi- eta hezur-hondakinak ugaritzearen ondorioz, hondakin solidoen problematika areagotu egin da azken hamarkadan. Arazo horri irtenbide bat emateko, animalia jatorria duten hondakinei irtenbide jasangarri bat emateko metodo eta tratamendu ezberdinak aztertu behar dira. Ildo honetan, epe laburrean arazoari eman dakiokeen irtenbideak aztertzen dira lan honetan.

Animalia-hezurren hondakinak osagai organikoz eta inorganikoz osatuta daude. Osagai organikoak gantzak eta proteinak dira gehien bat. Osagai inorganikoa, aldiz, fosfato eta karbonato gatzez eta karbonoz osatuta dago. Hondakinari balioa emateko osagai organikoa ezabatzea beharrezkoa da eta, nolabait, hondakina geldotzea.

Hondakina geldotzeko, oro har, tratamendu termikoa egin daiteke, pirolisiz zein errekuntzaz. Pirolisian substantzia baten degradazio termikoa ematen da oxigenorik gabeko baldintzetan. Hori dela eta, substantzia horiek beroarekin deskonposatzen dira, inolako errekuntza-erreakziorik gertatu gabe. Errekuntza, aldiz, oxigenoa duen atmosferan egindako tratamendu termikoa da. Jatorrizko animaliahondakinak kiskali ondoren lortutako azken produktua, substantzia trinko bat da, pisutan \%70-76 inguru kaltzio hidroxiapatitoa $\left(\mathrm{Ca}_{10}\left(\mathrm{PO}_{4}\right)_{6}(\mathrm{OH})_{2}\right)$ eta \%7-9 inguru kaltzio karbonatoa $\left(\mathrm{CaCO}_{3}\right)$ dena [4].

Hidroxiapatitoa (HAp) apatitoen familiako mineral bat da, hezurren zein hortz-haginen osagai arrunta, gogortasuna ematen diena, hain zuzen ere. Horretaz gain baditu beste ezaugarri berezi batzuk, hala nola, bere egitura osatzen duten $\mathrm{Ca}^{2+}$ eta $\mathrm{OH}^{-}$taldeak trukatzeko ahalmena. Izatez, animaliahondakinetatik eratorritako hidroxiapatitoak sodio eta magnesio katioiak eduki ditzake. Aldiz, $\mathrm{OH}^{-}$ taldea, beste anioi batek ordezkatu dezake, hala nola, kloroak, fluorrak edo bromoak, edo baita beste 
atomo-talde batzuk (sulfatoak eta karbonatoak) [5]. Horrela, apatitoen familiakoak diren kloroapatito, fluoroapatito eta bromoapatitoak, eta apatito karbonatodun edo sulfatodunak deritzen mineral isomorfoak eratzen dira.

Hidroxiapatitoa kimikoki ere sintetizatu daiteke, adibidez $\mathrm{pH}$ egokian $\mathrm{Ca}(\mathrm{OH})_{2}$ eta $\mathrm{H}_{3} \mathrm{PO}_{4}$ hauspeatuz [6]. Bere propietate fisiko-kimikoengatik hainbat erabilera proposatu dira hidroxiapatitoarentzako, besteak beste, biodegradagaitzak eta kaltegarriak diren substantziak (kutsatzaile organikoak eta metal astunak) isurkinetatik ezabatzeko zurgatzaile gisa [7,8], sistema katalitikoen euskarri gisa [9], aplikazio elektrokimikoetako elektrodo gisa eta biomedikuntzan [10].

Animalia-hondakinen tratamendu egokia eginda, apatitoz osatutako materiala erdietsi daiteke. Animalia-hondakinei balioa emateko prozedura egokiak garatzea lortuz gero, aplikazio askotarako erabil daitekeen apatitozko materiala ekoitzi daiteke, hondakin baliogabea den lehengai batetik abiatuta.

Espainia da Europar Batasuneko bigarren txerri-ekoizle handiena (1. Irudia). Adibidez, 2020 urtean 14 milioi tona txerri-haragi ekoiztu ziren [11]. Ondorioz, hidroxiapatitoan oinarritutako materialak txerri-hezurretatik prestatzea alternatiba errentagarria izan daiteke, prozesu hori ekonomikoki bideragarria eta ingurumenarekiko adiskidetsua dela kontuan hartuta.

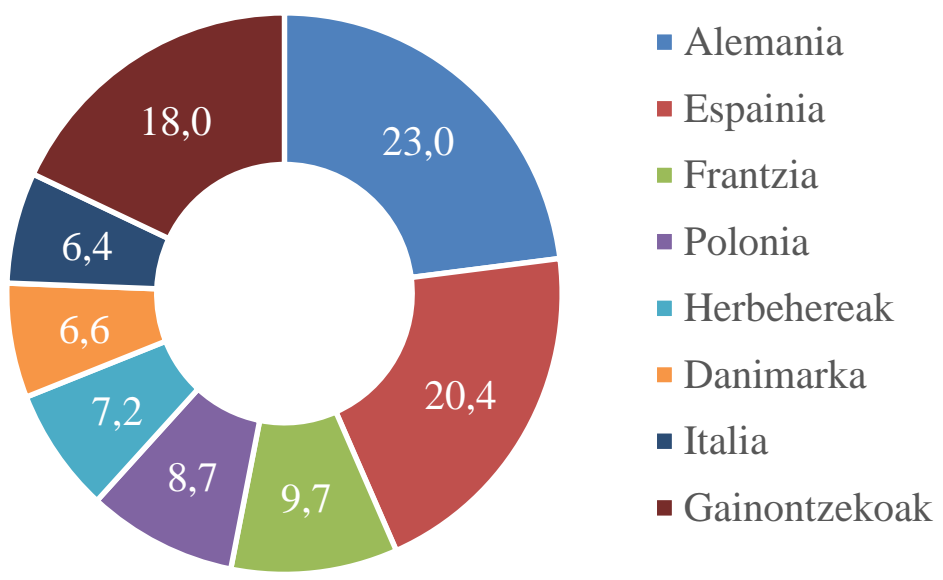

1. irudia. Europar Batasuneko herrialdeen txerri kopuru ekoizpena 2019an (ehunekotan emanda).

\section{PRESTAKETA}


Argitalpen zientifikoetan aurkitu daitezkeen ikerkuntza lanen arabera, hondakin-hezurrak geldotzeko eta material solido eta porotsu bihurtzeko tratamendu erabilienak aipatzen dira hurrengo ataletan. Eraldatze-prozesu horien helburua azken produktuaren ezaugarri fisiko eta kimiko batzuk garatzea da. Tratamendu hauek, maiz, aktibazio bezala adierazten dira.

\subsection{Tratamendu fisikoa}

Aktibazio fisikoa bakarrik erabili dela esaten da, hondakina soilik berotze-prozesu bidez eraldatzen denean. Kasu honetan kontrolatu beharreko aldagaiak gehienezko kiskaltze-tenperatura, tratamendudenbora, eta erabilitako atmosfera dira.

Animalia-hezurren aktibazio-baldintzak, azken produktuari emango zaion erabileraren arabera ezartzen dira. Oro har, lehenik eta behin hezurrean itsatsitako haragia eta koipea ezabatu behar dira, eta solido osoan berotze-prozesua homogeneoa izan dadin, 2-5 cm inguruko aletan xehetu. Ondoren, urarekin garbitzen da eta $105-110^{\circ} \mathrm{C}$ tartean lehortzen da [12-14].

Aktibazio fisikoa 300 eta $800{ }^{\circ} \mathrm{C}$ bitarteko tenperaturan egin ohi da ordu gutxi batzuko eta egun osoko tarteko iraupenaz. Kiskaltzeko bi modu daude: atmosfera oxidatzailea erabiltzea eta atmosfera inertea erabiltzea, hau da, pirolisia egitea. Pirolisian, beroak deskonposatzen du hondakina. Tratamendu honen produktuak gasak, likidoak eta hondar solidoak dira. Produktuaren etekina (lortutako hezur-ikatz masa hasierako hezur masako) hondakin-konposizioaren, pirolisi-tenperaturaren eta berotzeabiaduraren araberakoa da. Pirolisi-tenperatura txikietan produktu likido gehiago sortzen da; tenperatura handiek, aldiz, gas-produktuen sorrera sustatzen dute. Pirolisian sortutako gasean, ingurumenarentzat eta giza-osasunarentzat kaltegarriak diren hainbat substantzia aurki daitezke, hala nola, $\mathrm{H}_{2} \mathrm{~S}, \mathrm{NH}_{3}, \mathrm{SO}_{\mathrm{X}}$ eta $\mathrm{NO}_{\mathrm{x}}$ bezalako espezieak. Horregatik, ingurumenera isuri aurretik, gasa arazteko tratamenduak beharrezkoak dira [15]. Pirolisia egiteko gehien erabiltzen den gasa nitrogenoa den arren, beste atmosfera batzuk ere aztertu dira, produktu solidoaren ezaugarri fisiko-kimikoak aldatzeko. Adibidez, $\mathrm{CO}_{2}$ erabilita, azken produktu solidoaren porotasuna eta azalera espezifikoa handitzen dira [16].

\subsection{Tratamendu kimiko-fisikoa}

Aktibazioa egiteko tratamendu fisikoaren aurretik tratamendu kimikoa egin daiteke. Ikerlari batzuen baitan, solidoaren egitura porotsua hobeto garatzen da aktibazio kimikoa eta fisikoa konbinatuz [17]. Iriarte-Velasco eta lankideen [18] lanean ikus daiteke aktibazio kimikoarekin sortutako gasek poroen eraldatze-mekanismoan duten eragina eta ekarpena. 
Aktibazio kimikoa egin aurretik hondakina egokitu egin behar da, hezurrean dagoen haragia eta koipeak kendu eta tenperatura ertainetan kiskaliz, pirolisi- zein errekuntza-baldintzetan [19]. Tratamendu kimikoarekin ez dira aktibazio fisiko soilarekin erabiltzen diren baldintza zorrotzak erabiltzen. Ohikoak dira $400-500{ }^{\circ} \mathrm{C}$ tartea eta lau ordutik beherako iraupena [12,20]. Baldintza horiekin, hondar solido aitzindaria erdiesten da, haren gainean tratamendu kimikoa modu egokian egin daitekeena.

Aktibazio kimikorako substantzia ezorganikoak erabiltzen dira gehien bat. Gatzak $\left(\mathrm{ZnCl}_{2}, \mathrm{~K}_{2} \mathrm{CO}_{3}\right)$, alkali hidroxidoak (KOH, NaOH) [21] eta azidoak $\left(\mathrm{H}_{2} \mathrm{SO}_{4}, \mathrm{H}_{3} \mathrm{PO}_{4}, \mathrm{HNO}_{3}, \mathrm{HCl}\right)$ [22] ohikoak dira. Solido aitzindaria, aktibatzaile-disoluzioan murgildu eta nahi den denboraz mantentzen da, irabiatuta. Ordu gutxi batzuetatik egun osoko tartea da ohiko iraupena [23]. Aktibatzailearen kontzentrazioak eragin itzela dauka eta erabilitako aktibatzailearen erreaktibotasunaren eta kontaktu-denboraren arabera aukeratzen da. Aktibatzaile-disoluzioa 0,01- 3 M tarteko kontzentrazioekin hainbat ikerkuntza-lan aurkitu daitezke [12,24,25]. Bukatzeko, disoluziotik ateratzen da solidoa eta labean berotzen da, aktibazio fisikoa burutzeko, horrela solidoaren egitura porotsua garatzen baita eta, bide batez, erabilitako substantzia kimikoak ezabatzen dira.

\section{LORTUTAKO HEZUR-IKATZAREN KARAKTERIZAZIOA}

Solidoaren aktibazio-tratamendua egin ondoren, lortutako materialaren (hezur-ikatza) egitura eta haren propietateak aztertzeko eta neurtzeko hainbat teknika erabiltzen dira.

Ehundura propietateak, nitrogenoaren adsortzio-desortzio bidez neurtzen dira. Analisia egiteko, lagina $77 \mathrm{~K}$ arte hozten da. Halaber, lagina desgasifikatu egin behar da, hutsean, poroak hustutzeko (nitrogenoaren adsortzioa oztopatzen duten hezetasunez eta gasez beteta egoten baitira). Laburbilduz, laginak hartu duen nitrogeno kantitatearen eta zein presiotan hartzen duenaren arabera solidoaren azalera espezifikoa (eskaintzen duen azalera solido gramoko, $\mathrm{m}^{2} / \mathrm{g}$ ) eta poro-tamainen banaketa (tamaina bakoitzeko poroak azaleran duen ekarpena) eratorri daitezke, hainbat metodotan oinarrituta. Ohiko metodoen artean Brunauer, Emmett \& Teller (BET), dentsitate funtzionalaren teoria (DFT) eta Barrett, Joyner \& Halenda (BJH) metodoak daude. Metodo bakoitzak poroen ezaugarri jakin batzuetarako emaitza zuzena ematen duelako, laginaren poro-ezaugarrien arabera metodo horien artean aproposena aukeratu behar da. Poro-tamainaren arabera, hiru poro talde bereizten dira: $2 \mathrm{~nm}$ beherakoak (mikroporo), 2-50 nm tartekoak (mesoporo) eta $50 \mathrm{~nm}$ gorakoak (makroporo). Lortutako solidoan ekarpen handiena duen poro motak ematen dio izena solidoari. Adibidez, solido-mesoporotsu deitzen zaio batez ere mesoporoak dituen solidoari. 
Erdietsitako material solidoaren kristal-egitura, X izpien difrakzio (XRD) bidez aztertzen da (2. Irudia). Esperimentalki lortutako espektroa datu-baseetako espektroekin alderatuz, lortutako materialak apatito familiako egitura duela ondorioztatu dute hainbat ikertzailek. Kristalinitate-maila (hau da, hiru dimentsiotan partikulen ordenatze-maila geometrikoa) aldakorra da erabilitako aktibazio baldintzen arabera. Tratamendu fisikoan erabilitako tenperatura handiagoa den heinean solidoaren kristalinitatemaila handiagoa izaten da, hau da, geometrikoki ordenatuago daude partikulak eta unitate-gelaxka (kristal-sarean defini daitekeen paralelepipedorik txikiena) handiagoa eratzen dute. Aldiz, poro-kopurua murriztu egiten da poro-egitura eratzen duten hormak apurtu egiten baitira beroaren eraginez [26].

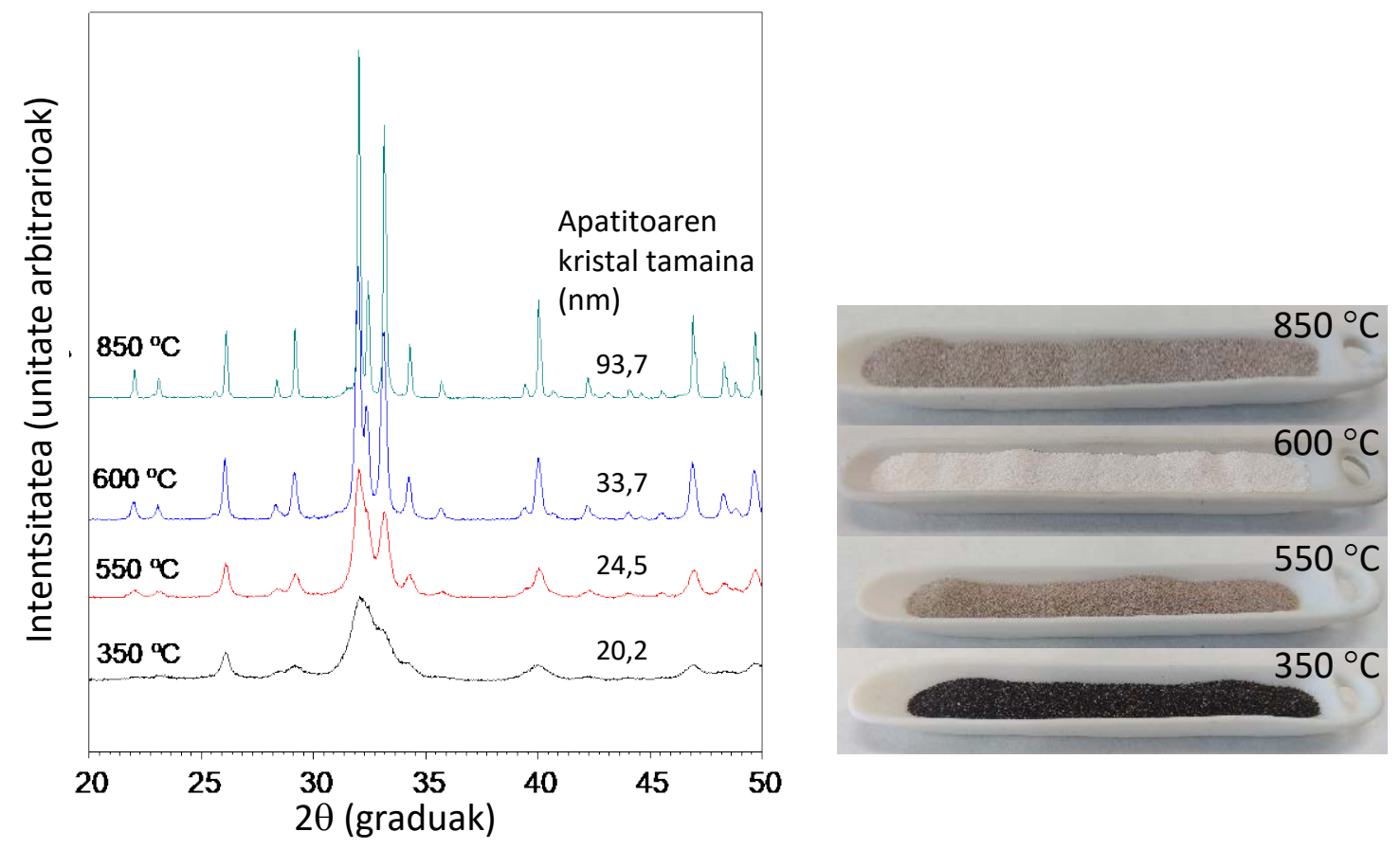

2. irudia. Hezur kiskalia eta horien XRD espektroak. Tenperatura handieneko bi laginak nitrogenotan berotuak (pirolisia) daude eta tenperatura txikieneko biak airetan kiskaliak (atmosfera oxidatzailetan) daude, tenperatura ezberdinetan.

Lortutako solidoaren egonkortasun termikoari buruzko informazioa analisi termograbimetrikoak (TGA) ematen du. Saiakuntza tipikoan, $200-900{ }^{\circ} \mathrm{C}$ tarteko tenperatura arte berotzen da solidoa, airejarioan, $5-10^{\circ} \mathrm{C} / \mathrm{min}$ berotze-abiadurarekin $[13,23]$. Analisi honekin, lortutako solidoa zein tenperaturan deskonposatzen den jakin daiteke (3. Irudia). Informazio hau kritikoa da hezur-ikatza erabiliko den aplikazio batzuetan. Adibidez, katalizatzaileen euskarri moduan erabiltzen bada, erreakzio tenperaturan 
egonkorra izan behar da. 3a eta $3 \mathrm{~b}$ irudien arabera, $500{ }^{\circ} \mathrm{C}$ inguru arte gertatzen da solidoaren deskonposatze handiena, eta hortik goragoko tenperaturan, egonkorragoa da (masa gutxiago galtzen da). Ikusten denez, aktibatu gabeko solidoak masa gutxiago galtzen du azido fosforikoarekin tratatutakoarekin alderatuz.
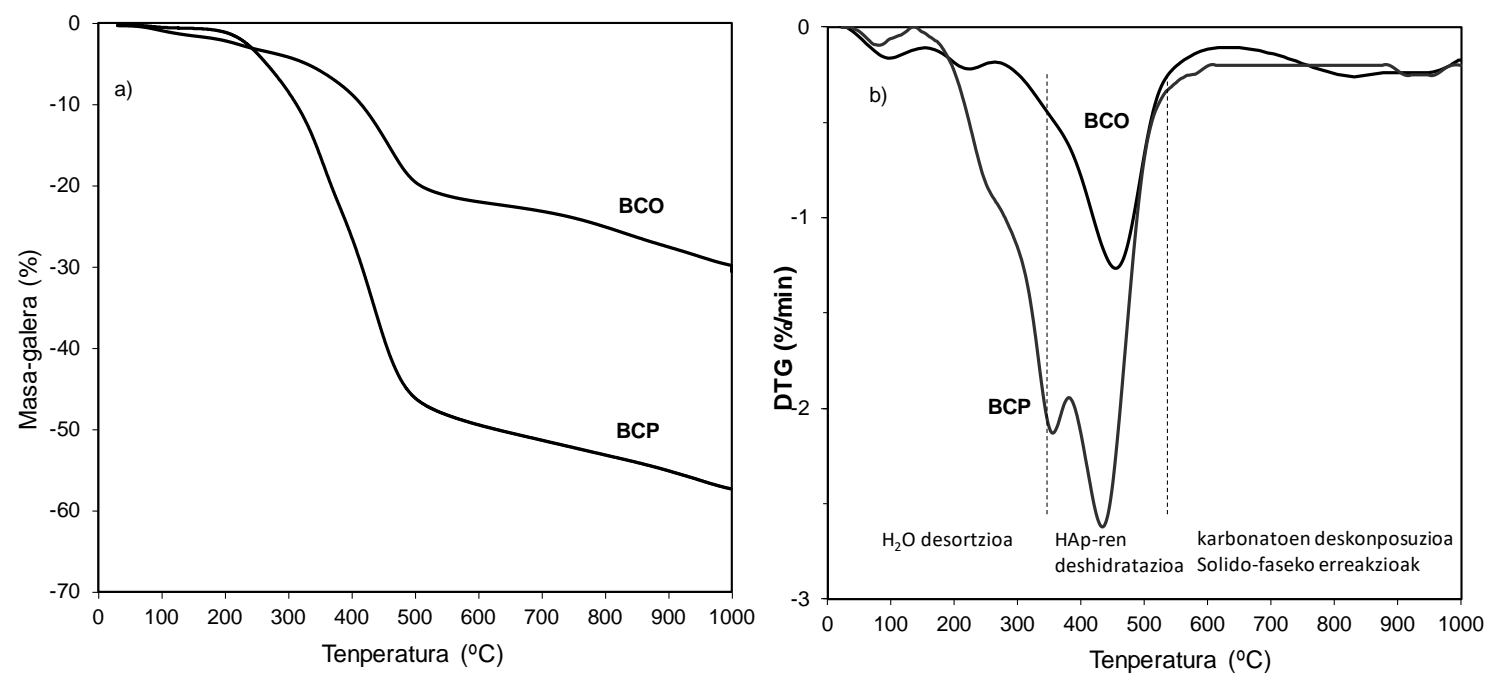

3. irudia. HAp euskarriaren azterketa termograbimetrikoa, aktibatu gabea (BCO) eta $\mathrm{H}_{3} \mathrm{PO}_{4}$-kin aktibatua. a) Guztizko masa-galera b) Masa-galera abiadura. [18].

Gainazalaren morfologia eta egitura zehazteko hainbat teknika erabiltzen dira. Haien artean, ekortze-mikroskopia elektronikoa (SEM) dago, solidoaren "argazki-irudiak” ematen dituena. Halaber, gainazalaren analisi kimikoa X-izpiak erabiltzen dituzten teknika bidez egin daiteke, hala nola, $\mathrm{X}$-izpien bidezko espektroskopia fotoelektronikoa (XPS) edo X-izpien energia dispertsio analisia (EDX).

Infragorri-espektroskopia (FTIR) bitartez, gainazaleko talde molekularrei buruzko informazioa lor daiteke. Saiakuntza hau egiteko lagina birrindu eta lortutako hautsarekin (KBr-rekin nahastuz) pikor edo pastillatxoa prestatzen da prentsaren presiopean. Pastillatxoa mehea izan behar da IR uhinek zeharkatu egin behar baitute. Neurketa egin ondoren lortutako datuak software baten laguntzaz aztertzen dira, bibrazio-maiztasuna absorbantzia zein transmitantzia moduan eman daitekeela. FTIR seinalea 500-4000 $\mathrm{cm}^{-1}$ tartean neurtzen da (4. Irudia). Halako teknikaren bitartez ikusten diren apatitoen ezaugarri diren transmitantzia-seinaleak hauek dira: 567, 603 eta $1037 \mathrm{~cm}^{-1}$ inguruko gailurrek P-O loturaren bibrazioa adierazten dute, $\mathrm{PO}_{3}{ }^{-}$funtzio-taldearen adierazgarri; 1415 eta $1456 \mathrm{~cm}^{-1}$ seinale-bikotea karbonatoko CO loturaren bibrazio simetrikoari dagokio. Halaber, hidroxiapatitoa bada solidoaren osagai nagusi, bereizgarriak diren $\mathrm{OH}^{-}$funtzio-taldeak nabarmenduko dira, 633 eta $3572 \mathrm{~cm}^{-1}$ inguruan. Aldiz, azken 
transmitantzia-seinale horiek ez badira agertzen, hidroxilo ioiak beste anioiren batek ordezkatu dituenaren seinale da (fluoroapatita edo kloroapatita motako solidoak, adibidez). FTIR analisiarekin, halaber, karbonatoan aberatsa den edo materia organiko arrastorik duen jakin daiteke. Ezaugarri guzti hauek, noski, hezur-ikatzari emango zaion erabileraren arabera garrantzitsuak izan daitezke, materialaren izaera kimiko eta fisikoan eragiten bait dute.

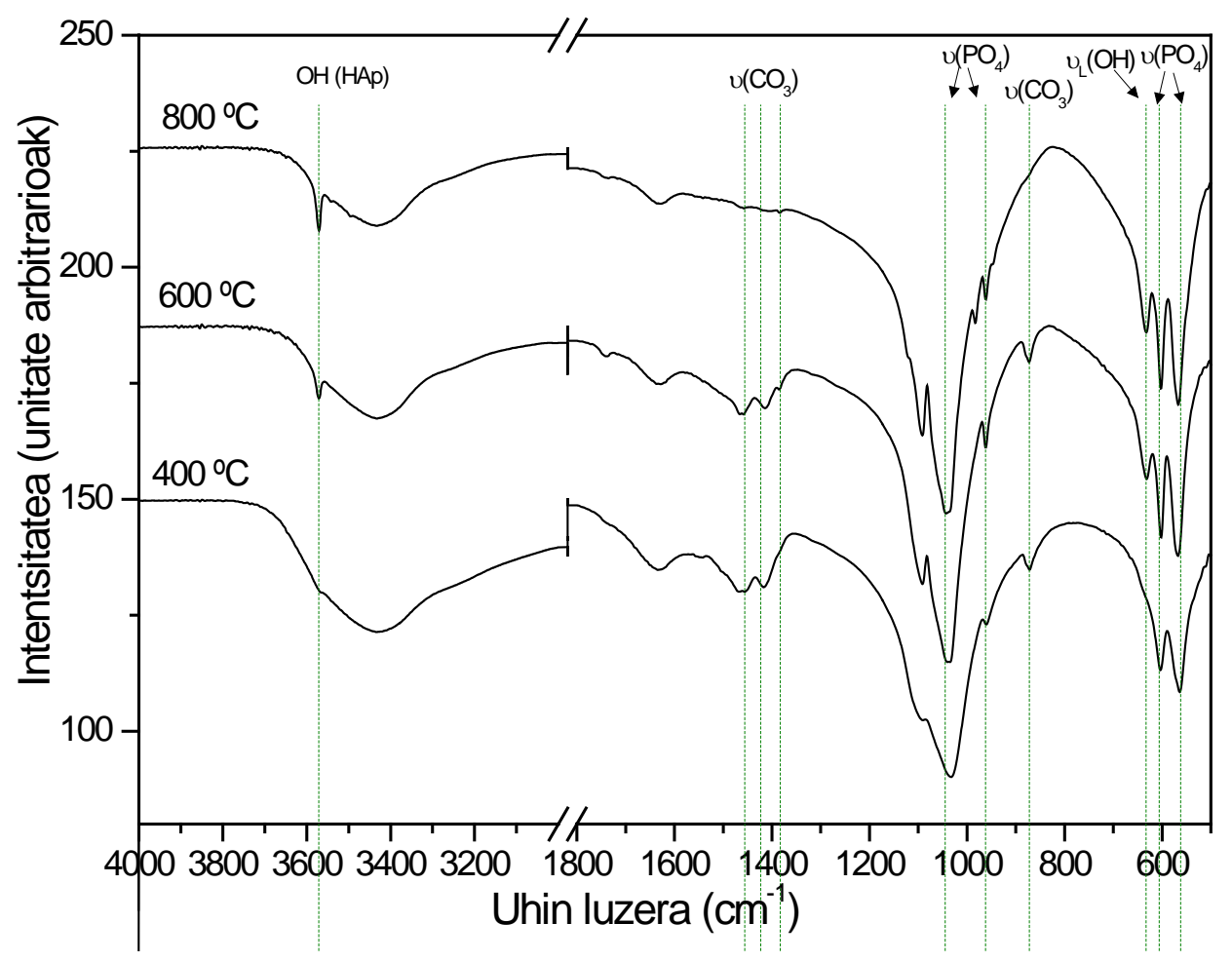

4. irudia. Hainbat tenperaturatan kiskaldutako hezur hondakinen FTIR analisia.

\section{ERABILPEN ADIBIDE BATZUK}

Azken hamarkadan ikerketa ugari egin da animalia-hezurren hondakinak eraldatu eta balioa ematen dien irtenbide egokiak aztertzeko. Lortutako hezur-ikatzarentzako aplikazio anitz proposatu dira, hondakin horiei bigarren erabilera bat emateko.

Adibidez, hondakin horien balorizazio energetikoa aztertu da, zentral termikoetan edo zementugintzan erabili ohi den erregaiari, animalia-hondakin horien zati txiki bat gehituz. $[27,28]$. 
Jasangarritasunaren ikuspuntutik ez da hezur-hondakinentzako irtenbide egokiena, errekuntzan dioxina eta furanoak aska daitezkeelako [29], eta NOx bezalako espezie kaltegarriak sortu daitezkeelako [30].

Apatitoaren fosfato-eduki handiagatik, ongarriak egiteko ere erabili da hezur-hondakina. Ameriketako Estatu Batuetan, adibidez, nekazal-jardueretan mantenugai-nahasteak egiteko erabili izan da [31].

Goodman eta lankideek (2013) [32], adibidez, pirolizatutako behi hezurretatik abiatuz, superkondentsadore elektrodo gisa erabiltzeko azalera eta porotasun handiko karbonozko monolitoak prestatu eta karakterizatu dituzte. Prestakuntzan, animalia-hondakinak $1000{ }^{\circ} \mathrm{C}$-ra pirolizatu zituzten (ohiko tenperatura baino handiagoa) hidroxiapatitoa guztiz ezabatu eta karbonoz osaturiko materiala emateko. SEM irudiek jatorrizko hezurren poro-egitura hierarkikoa mantentzen dela erakusten dute, makroporo eta mesoporoz osatua. Lortutako karbono monolitoek grafeno itxurako xaflak dituzte, elkar itsatsi gabekoak eta, ondorioz, eroankortasun elektriko eta azalera handiko (BET gainazala $1383 \mathrm{~m}^{2} / \mathrm{g}$ ) egiturak dira.

Behien eta txerrien hezurretatik eskuratutako hidroxiapatitozko protesiekin aurrerapenak egin dira ortopedian [33]. Adibidez, gizakiotan galdu diren ehunak ordezkatzeko edo hezurretako akatsak tratatzeko erabili izan da [34]. Ikerlari horien kasuan, metodo ezberdinak erabili zituzten HAp eskuratzeko eta hezurrak ordezkatu ahal izateko.

Aurretik aipatutako erabilpenez gain, hezur- eta animalia-hondakinei balioa emateko irtenbide arruntenak material zurgatzaile eta katalizatzaile-euskarri bihurtzea dira. Yang eta lankideek (2020) [12], behien hondakin-hezurretatik abiatuta, konposatu organiko lurrunkorren adsortzio azkar eta eraginkorrerako baliagarri den material porotsua lortu dute, aktibazio kimiko-fisikoa erabiliz. Lehenbizi, hondakina $450{ }^{\circ} \mathrm{C}$-an pirolisi baldintzetan geldotzen dute. Tratamendu kimikoan erabilitako $\mathrm{K}_{2} \mathrm{CO}_{3}-\mathrm{ren}$ deskonposizioan solidoaren gainazaleko zimurtasuna handitzen duten hainbat gas-espezie askatzen direla ikusi zuten. 5. Irudian hainbat modutan aktibatutako hezur kiskaliaren gainazal-egitura erakusten da. Ikus daiteke, hezurrak $\mathrm{H}_{3} \mathrm{PO}_{4}$-rekin tratatuz material mesoporotsua erdiesten dela. Aldiz, $\mathrm{K}_{2} \mathrm{CO}_{3^{-}}$ rekin aktibatzean, gainazalean hainbat "akats” eta tarte txiki eratzen dira, mikroporo kopurua handituz. Gainera, akats horiek konposatu organiko lurrunkorren adsortzio-prozesua nabarmen azkartzen dutela ikusi dute. 


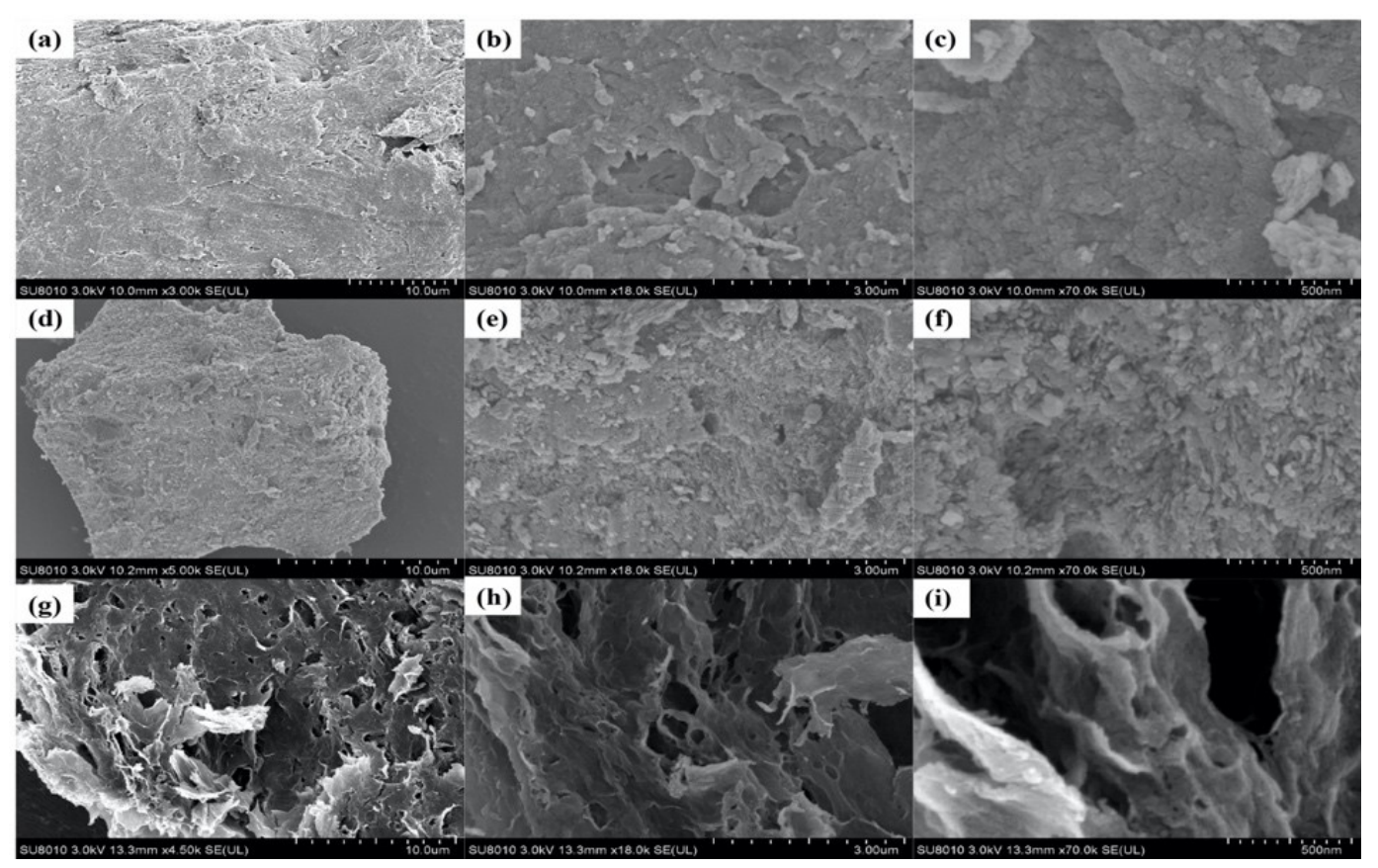

5. irudia. Hondakin hezur aktibatuaren gainazal SEM irudiak. (a)-(c): Hezur kiskalia, (d)-(f): Azidoarekin $\left(\mathrm{H}_{3} \mathrm{PO}_{4}\right)$ aktibatuta eta (g)-(i): Alkali bidez $\left(\mathrm{K}_{2} \mathrm{CO}_{3}\right)$ aktibatuta. Yang eta lankideak (2020) [12].

Obadiah eta lankideek (2012) [35] animalien hondakin-hezurretatik lortutako apatitoa, palmaolioaren transesterifikaziorako katalizatzaile eraginkor gisa erabili dute. Hezur-hondakina hainbat tenperaturatan kiskaltzen dute (200, 400, 600 eta $\left.800{ }^{\circ} \mathrm{C}\right)$, hezurretako kaltzio fosfatoa hidroxiapatito bihurtzeko. Hezurren zati ezorganikoa, gehien bat, kaltzioz eta fosforoz osatua zegoela ikusi dute, baina beste elementu batzuk ere behatu dituzte, kantitate txikiagotan (C, Na eta Mg). Ikerlari hauen arabera, hezurren kiskaltze-tenperatura handitu ahala, lortutako solidoaren katalisi-aktibitatea handitu egiten da, orduan eta hidroxiapatito gehiago lortzen delako. Hala ere, tenperatura $800^{\circ} \mathrm{C}$ baino handiagotan, efektu hori desagertu egiten da.

UPV/EHUko Iriarte-Velasco eta lagunek [36,37], txerri-hezurretatik eratorritako hidroxiapatita prestatu dute, katalisirako euskarri zein tinteen adsortziorako zurgatzaile baliagarriak direla balioztatuz. Adsortziorako zurgatzaile gisa erabiltzeko prestakuntzan, aktibazio kimiko-fisikoa burutu dute, $800{ }^{\circ} \mathrm{C}$ ra kiskaliz, airetan. Aktibazio kimikoan $\mathrm{NaOH}, \mathrm{K}_{2} \mathrm{CO}_{3}$, eta $\mathrm{H}_{2} \mathrm{SO}_{4}$ erabiltzean, solidoaren gainazal espezifikoa handitzen da (\%53ko handitze maximoa lortu arte); $\mathrm{KOH}$ tratamenduak eragin txikia dauka solidoaren egitura porotsuan, eta $\mathrm{H}_{3} \mathrm{PO}_{4}$ tratamenduak, aldiz, gainazal espezifikoa eta poro-bolumena guztiz ezabatzen ditu. Lortutako solidoa tinta organikoen adsortzioan erabili dute (6. Irudia). Ikus daitekeen moduan, $\mathrm{H}_{2} \mathrm{SO}_{4}$ tratamenduarekin lortutako solidoak aktibaziorik gabeko solidoak baino 
askoz ere arinago zurgatzen du metilenoaren urdina (erabilitako tinta esanguratsua) eta gainera, adsortzio-gune gehiago ditu. Horien guztien eragilea egitura porotsu desberdina da, izan ere, $\mathrm{H}_{2} \mathrm{SO}_{4}{ }^{-}$ rekin aktibatutako solidoan poroen \%70a mikroporoak dira, aktibatu gabekoan \%45eraino gutxitzen dena.
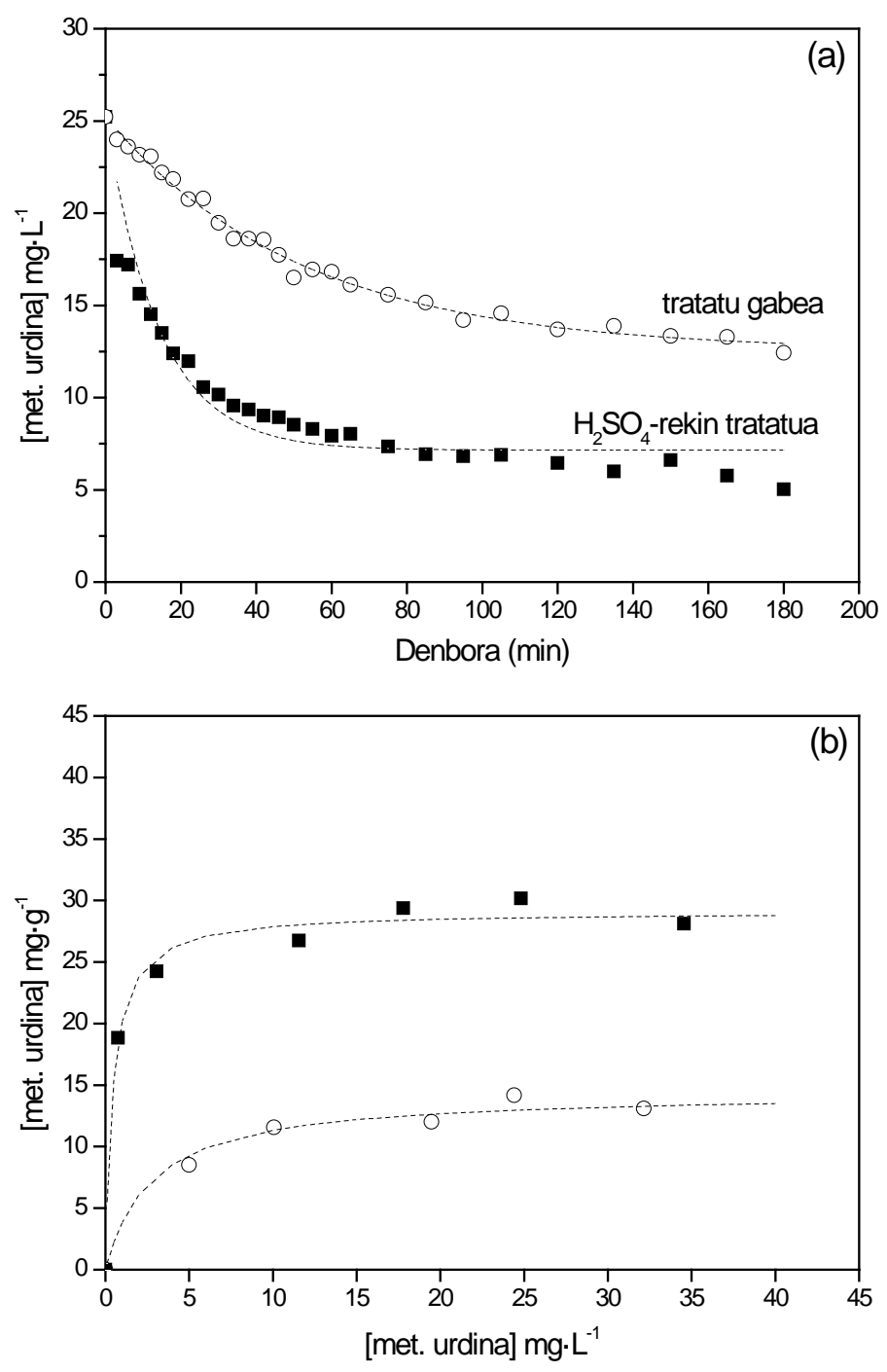

6. irudia Metileno urdinaren adsortzio zinetika (a) eta oreka (b) aktibaziorik gabeko solidoan eta aktibazio kimiko-fisikoa izan duen solidoan.

Katalizatzaile-euskarri bezala era erabili dute ikerlari hauek hezurretik lortutako hidroxiapatitoa [37]. Aplikazio katalitikoa hidrogenoa kutsatzen duen CO ezabatzea izan da. Egin kontu, hidrogenoa lortzeko gaur egun erabiltzen diren prozesu termokimikoetan hidrogenoaz gain CO ere lortzen dela, eta honek PEM (Proton Exchange Membrane) erregai-pilen anodoa kutsatzen duela. Beraz, hidrogenoa 
ekoizteaz gain, honi CO kendu behar zaio, besteak beste, Water-Gas Shift (WGS) izeneko erreakzio kimikoan. WGS erreakzio honetarako $\left(\mathrm{CO}+\mathrm{H}_{2} \mathrm{O} \leftrightarrows \mathrm{CO}_{2}+\mathrm{H}_{2} \mathrm{O}\right)$ eraginkorrak, egonkorrak eta hautakorrak diren katalizatzaileak garatzea ezinbestekoa da hidrogeno-ekonomia sustatzeko. Aldibereko erreakzioak ere gerta daitezke, COaren metanazioa, adibidez. Honek hidrogenoa kontsumitzen du eta, ondorioz, prozesuaren eraginkortasuna txikitu. WGS erreakzioan euskarri aplikaziorako hezurrei tratamendu fisikoa egin zaie bakarrik (airetan kiskali dira $500{ }^{\circ} \mathrm{C}-\mathrm{ra}, 5{ }^{\circ} \mathrm{C} / \mathrm{min}$ arrapalaz). Solidoaren gainean WGS erreakziorako eraginkorrak diren metal desberdinen artean ( $\mathrm{Ni}$, $\mathrm{Cu}$, Co eta $\mathrm{Fe}$ ) eraginkorrena Ni dela ikusi dute, \%10eko edukiarekin. Erreferentzia gisa erabilitako sintetikoki prestatutako hidroxiapatitarekin COaren bihurtze-maila handiagoa lortzen duten arren, honek metano gehiago ekoizten du (hau da, hidrogeno etekin txikiagoa ematen du). 7. Irudian ikus daiteke, hezurren aktibazio-baldintzen arabera modu esanguratsuan hobetu daitekeela erdietsitako materialaren katalisiaktibitatea. Hezurretik lortutako euskarriarekin hidrogeno etekin handiagoa lortzen da, hidroxiapatita sintetikoak baino gune basiko gehiago dituelako eta, kantitate txikian baina eragin nabarmena duten metal alkalinoak dituelako.

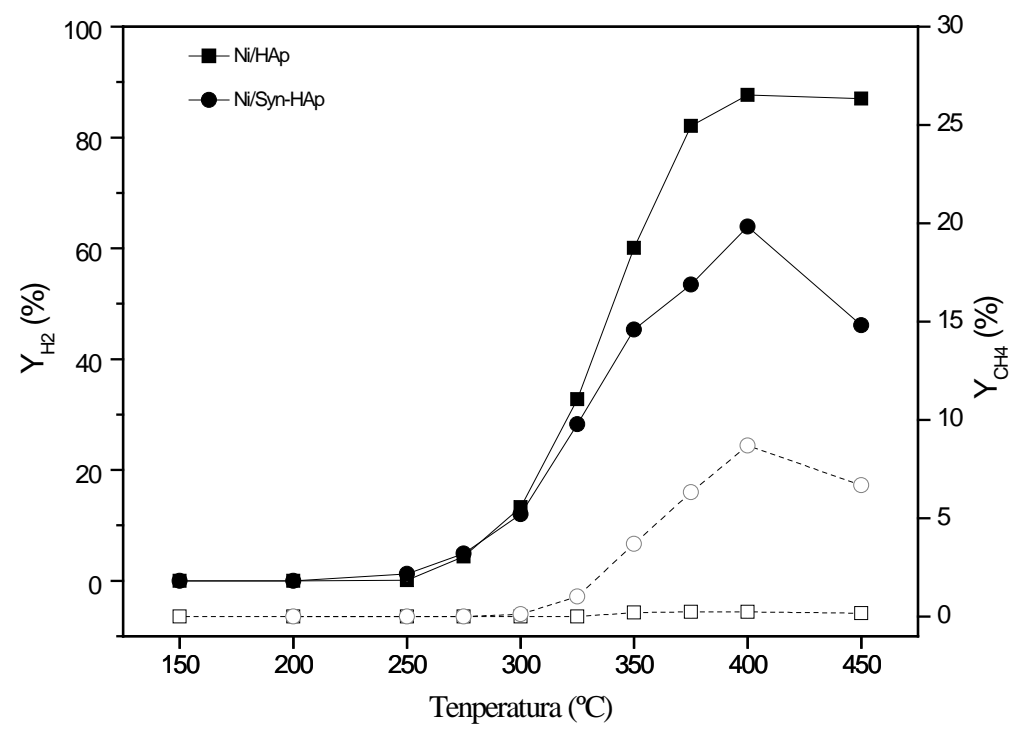

7. irudia Hidrogenoaren eta metanoaren etekinen tenperatura bilakaera hidroxiapatito sintetikoa eta txerri-hezurretatik eratorritako hidroxiapatitoa nikelaren euskarri bezala erabiliz.

\section{ONDORIOAK}


Abereak elikatzeko animalia-haragi eta hezurrekin egindako irina erabiltzearen debekuaren ostean, hondakin solidoen problematika areagotu egin da azken hamarkadan. Animalia-jatorria duten hondakinei irtenbide jasangarria emateko helburuarekin, metodo eta tratamendu ezberdinak aztertu behar dira.

Hainbat ikerketa-talde hondakin horiei erabilera berriak bilatzen dihardute, beti ere garapen iraunkorra bermatzeko, animalia-hezurretan aberatsa den hidroxiapatitoaren ezaugarri faboragarrietan oinarrituta. Horretarako, balio-emate teknologia edo prozedura berriak garatu beharra dago. Aktibazio prozedura egokia eraginez gero, hainbat aplikaziotarako baliagarria den azken produktua erdietsi bait daiteke.

Apatito naturala katalizatzaile-euskarri eta tinta organikoen zurgatzaile gisa erabili da nagusiki. Hala ere, badago animalia-hondakin horien balorizazio energetikoa egitea proposatu duenik, erregaiari zati txiki bat gehituz. Gainera, hezur horietatik abiatuz, eraginkortasun handiko superkondentsadore elektrodo gisa erabiltzeko karbono monolitoak ere prestatzea lortu da.

Material horren aplikagarritasuna bere egitura porotsuarekin zuzenean lotuta dagoenez, porotasunmaila desberdina garatzeko aktibazio kimiko edo/eta fisikoaren beharra dago. Aktibazio kimikoa, soilik fisikoa baino abantailatsuagoa da, gehienbat, lortutako etekina handiagoa delako eta lortzen den azken materialaren gainazal-azalera handiagoa delako. Halaber, aurrez aktibazio kimikoa egitean, aktibazio fisikoaren tenperatura txikiagoak behar dira.

Aktibazioaren eraginkortasuna hainbat faktoreren menpekoa da. Hala nola hondakinaren konposizioa, erabilitako aktibatzaile mota, gehienezko tenperatura, denbora eta kiskaltzea burutu den atmosfera. Horregatik, faktore horiek modu ezberdinean konbinatzeak eragin nabarmena du lortutako materialean eta beraz, material horren aplikazioan.

Kimikoki sintetizatutako apatitoek erakutsitako aktibitate katalitikoarekin alderatuz, euskarri naturalak etorkizunean aukera ugari izan ditzakeela ondoriozta daiteke. Halaber, hainbat jatorritatik lortutako HAp naturalarekin egindako ikerketak beharrezkoak dira erreproduzigarritasun arazoak gainditzeko.

\section{ESKER ONAK}


Artikulu honek UPV/EHUren, Eusko Jaurlaritzaren (GV-2018-00038 proiektua) eta Espainiako Ekonomia eta Lehiakortasun Ministeritzaren (ENE2016-74850-R) dirulaguntza jaso du.

\section{BIBLIOGRAFIA}

[1] ROBERTS, G.W. eta JAMES, S. 1996. «Prion diseases: transmission from mad cows? ». Current biology, 1, 1247-1249.

[2] World health organization, 2005, Manual de bioseguridad en el laboratorio. https://www.who.int.

[3] Directiva 1999/31/CE de 21 de octubre de 2009 por el que se establecen las normas sanitarias aplicables a los subproductos animales y los productos derivados no destinados al consumo humano [4] K. ISHIKAWA, K., MIYAMOTO, Y., TSUCHIYA, A., HAYASHI, K., TSURU, K., OHE G. 2018 «Physical and histological comparison of hydroxyapatite, carbonate apatite, and $\beta$-tricalcium phosphate bone substitutes». Materials, 11, 704-719.

[5] CACCIOTTI, I. 2016. Cationic and Anionic Substitutions in Hydroxyapatite. Handbook of Bioceramics and Biocomposites-en. Springer, Suitza.

[6] MOHD PU'AD, N.A.S., ABDUL HAQ, R.H., MOHD NOH, H., ABDULLAH, H.Z., IDRIS, M.I. eta LEE, T.C. 2020. «Synthesis method of hydroxyapatite: A review». Materials Today: Proceedings, 29, 233-239.

[7] CIOBANU, G., HARJA, M., RUSU, L., MOCANU, A. eta LUCA, C. 2014. «Acid black 172 dye adsorption fromaqueous solution by hydroxyapatite as low-cost adsorbent». Korean Journal of Chemical Engineering, 31, 1021-1027.

[8] KIM, Y. eta LEE, Y.J. 2014. «Characterization of mercury sorption on hydroxylapatite: Batch studies and microscopic evidence for adsorption». Journal of Colloid and Interface Science, 430, 193199.

[9] CHUN, S.Y, AN, S.W., LEE, S.J., KIM, J.T. eta CHANG, S.W. 2014. «Optimization of sulfamethoxazole degradation by $\mathrm{TiO}_{2}$ /hydroxyapatite composite under ultraviolet irradiation using responsesurface methodology». Korean Journal of Chemical Engineering, 31, 994-1001.

[10] AWASTHI, S., PANDEY, S.K., ARUNAN, E., eta SRIVASTAVA, S. «A review on hydroxyapatite coatings for the biomedical applications: experimental and theoretical perspectives», Journal of materials chemistry B, 9, 228-249. 
[11] Ministerio de agricultura pesca y alimentación, Estadísticas agrarias: Ganadería. Argitaratua azaroak 2020, https://www.mapa.gob.es

[12] YANG, Y., SUN, C., LIN, B. eta HUANG, Q. 2020. «Surface modified and activated waste bone char for rapid and efficient VOCs adsorption». Chemosphere, 256, 127054.

[13] ALKURDI, S.S.A., AL-JUBOORI, R.A., BUNDSCHUH, J., BOWTELL, L. eta MCKNIGHT, S. 2020. «Effect of pyrolysis conditions on bone char characterization and its ability for arsenic and fluoride removal». Environmental Pollution, 262, 114221.

[14] PATEL, S., HAN, J. eta GAO, W. 2015. «Sorption of 17ß-estradiol from aqueous solutions on to bone char derived from waste cattle bones: Kinetics and isotherms». Journal of Environmental Chemical Engineering, 3, 1562-1569.

[15] FOGARASSY, C, TOTH, L., CZIKKELY, M. AND FINGER, D.C. «Improving the E ciency of Pyrolysis and Increasing the Quality of Gas Production through Optimization of Prototype Systems» Resoources, 8, 182-196.

[16] ROJAS-MAYORGA, C.K., SILVESTRE-ALBERO, J., AGUAYO-VILLARREAL, I.A., MENDOZA-CASTILLO, D.I. eta BONILLA-PETRICIOLET, A., 2015. «A new synthesis route for bone chars using $\mathrm{CO} 2$ atmosphere and their application as fluoride adsorbents». Microporous and Mesoporous Materials, 209, 38-44.

[17] JIMENEZ-CORDERO, D., HERAS, F., ALONSO-MORALES, N., GILARRANZ, M.A. eta RODRIGUEZ, J.J. 2013. «Development of porosity upon physical activation of grape seeds char by gas phase oxygen chemisorption-desorption cycles». Chemical Engineering Journal, 231, 172-181.

[18] IRIARTE-VELASCO, U., AYASTUY, J.L., ZUDAIRE, L. eta SIERRA, I. 2014. «An insight into the reactions occurring during the chemical activation of bone char». Chemical Engineering Journal, 251, 217-227.

[19] DEYDIER, E., GUILET, R., SARDA, S. eta SHARROCK, P. 2005. «Physical and chemical characterisation of crude meat and bone meal combustion residue: waste or raw material?». Journal of Hazardous Materials, 121, 141-148.

[20] ZHOU, X., ZENG, Z., ZENG, G., LAI, C., XIAO, R., LIU, S., HUANG, D., QIN, L., LIU, X., LI, B., YI, H., FU, Y., LI, L. eta WANG, Z. 2020. «Persulfate activation by swine bone char-derived hierarchicalporous carbon: Multiple mechanism system for organic pollutant degradation in aqueous media». Chemical Engineering Journal, 383, 123091. 
[21] WEI, S., ZHANG, H., HUANG, Y., WANG, W., XIA, Y. eta YU, Z. 2011. «Pig bone derived hierarchicalporous carbon and its enhanced cycling performance of lithium-sulfur batteries». Energy \& Environmental Science, 4, 736-740.

[22] BILAL SHAKOOR, M., ALI, S., RIZWAN, M., ABBAS, F., BIBI, I., RIAZ, M., KHALIL, U., KHAN NIAZI,. N eta RINKLEBE, J. 2020. «A review of biochar-based sorbents for separation of heavy metals from water». International Journal of Phytoremediation, 22, 111-126.

[23] PENG, W., ZHANG, H., LÜ, F., SHAO, L. eta HE, P. 2021. «Char derived from food waste based solid digestate for phosphate adsorption». Journal of Cleaner Production, 297, 126687.

[24] LIU, K., LI, F., TIAN, Q., NIE, C., MA, Y., ZHU, Z., FANG, L., HUANG, Y. eta LIU, S. 2021. «A highly porous animal bone-derived char with a superiority of promoting nZVI for $\operatorname{Cr}(\mathrm{VI})$ sequestration in agricultural soils». Journal of Environmental Sciences, 104, 27-39.

[25] DENG, L., ZHANG, Y., WANG, Y., YUAN, H., CHEN, Y. eta WU, Y. 2021. «In situ N-, P- and Ca- codoped biochar derived from animal bones to boost the electrocatalytic hydrogen evolution reaction». Resources, Conservation and Recycling, 170, 105568.

[26] BISWAS, P.P., LIANG, B., TURNER-WALKER, G., RATHOD, J., LEE, Y.C., WANG, C.C., eta CHANG, C.K. 2021. «Systematic changes of bone hydroxyapatite along a charring temperature gradient: An integrative study with dissolution behavior». Science of the Total Environment, 766, 142601.

[27] SENNECA, O. 2008. «Characterisation of meat and bone mill for coal co-firing». Fuel, 87, 32623270.

[28] SKODRAS, G., GRAMMELIS, P. eta BASINAS, P. 2007. «Pyrolysis and combustion behaviour of coal-MBM blends». Bioresource Technology, 98, 1-8.

[29] CONESA, J.A., FULLANA, A. eta FONT, R. 2005. «Dioxin production during the thermal treatment of meat and bone meal residues». Chemosphere, 59, 85-90.

[30] CUMMINS, E.J., MCDONNELL, K.P. eta WARD, S.M. 2006. «Dispersion modelling and measurement ofemissions from the co-combustion of meat and bone meal with peat in a fluidised bed». Bioresource Technology, 97, 903-913.

[31] MARTIN GRAFE, M., KURTHA, J.K., PANTEN, K., RAJ, A.D., BAUM, C., ZIMMER, D., LEINWEBER, P., SCHLOTER, M. eta SCHULZ, S. 2021. «Effects of different innovative bone char 
based P fertilizers on bacteria catalyzing P turnover in agricultural soils». Agriculture ecosystems Environment, 314, 107419.

[32] GOODMAN, P.A., LI, H., GAO, Y., LU, Y.F., STENGER-SMITH, J.D. eta REDEPENNING, J. 2013. «Preparation and characterization of high surface area, high porosity carbon monoliths from pyrolyzed bovine bone and their performance as supercapacitor electrodes». Carbon, 55, 291-298.

[33] SOBCZAK-KUPIEC, A., WZOREK, Z., KIJKOWSKA, R. eta KOWALSKI, Z. 2013. «Effect of calcination conditions of pork bone sludge on behaviour of hydroxyapatite in simulated body fluid». Bulletin of Materials Science, 36, 755-764.

[34] STAVROPOULOS, A. eta KARRING, T. 2010. «Guided tissue regeneration combined with a deproteinized bovine bone mineral (Bio-Oss) in the treatment of intrabony periodontal defects: 6-year results from a randomized-controlled clinical trial». Journal of Clinical Periodontology, 37, 200-210. [35] OBADIAH, A., SWAROOPA, G.A., KUMAR, S.V., JEGANATHAN, K.R. eta RAMASUBBU, A. 2012. «Biodiesel production from Palm oil using calcined waste animal bone as catalyst». Bioresource Technology, 116, 512-516.

[36] IRIARTE-VELASCO, U., SIERRA, I., ZUDAIRE, L., eta AYASTUY, J. L. 2016. «Preparation of a porous biochar from the acid activation of pork bones». Food and Bioproducts Processing, 98, 341-353.

[37] IRIARTE-VELASCO, U., AYASTUY, J.L., BOUKHA, Z., BRAVO, R. eta GUTIERREZORTIZ, M.A. 2018. «Transition metals supported on bone-derived hydroxyapatite as potential catalysts for theWater-Gas Shift reaction». Renewable Energy, 115, 641-648. 